Vol. 3 No.2 (2020) pp. 57-67

Research Paper

\title{
An Experimental Study of the Addition of Air Mass Flow Rate Using a 30\% Emulsion-Fueled Diesel Engine at High Load
}

\author{
Rosid Rosid ${ }^{1,3} \square$, Bambang Sudarmanta ${ }^{1}$, Lukman Atmaja ${ }^{2}$, Salih Ozer ${ }^{4}$ \\ ${ }^{1}$ Department of Mechanical Engineering, Institut Teknologi Sepuluh Nopember Surabaya, Surabaya 60111, \\ Indonesia \\ ${ }^{2}$ Department of Chemistry, Institut Teknologi Sepuluh Nopember Surabaya, Surabaya 60111, Indonesia \\ ${ }^{3}$ Department of Mechanical Engineering, Universitas Singaperbangsa Karawang, Karawang 41360, Indonesia \\ ${ }^{4}$ Department of Mechanical Engineering, Mus Alparslan University, Mus 49250, Turkey
}

rosid@ft.unsika.ac.id

(d) https://doi.org/10.31603/ae.v3i2.3618

Check for updates

Article Info

Submitted: $16 / 05 / 2020$

Revised:

$16 / 06 / 2020$

Accepted:

$17 / 06 / 2020$

\section{Abstract}

This study aims to examines the addition of air mass flow rate into the combustion chamber using E30 emulsion fuel (Water 70\% + Dex 30\% + 2\% surfactant tween $80+$ span 80 ) on a Diamond DI 800 stationary diesel engine on $1500 \mathrm{rpm}$. Engine performance was evaluated using a combustion analyzer and emissions measured with an engine gas analyzer. The results showed the addition of air mass flow rate affected engine performance and emissions. Output power observed to have decreased by $0.016 \%$ while SFC and thermal efficiency increased by 2,077\% and 33,053\%, respectively, compared to diesel fuel. Moreover, the BMEP and exhaust temperature also decreased, the most optimal reduction in BMEP was found to be $0.02 \%$ and the most optimum reduction in exhaust gas temperatures at $285{ }^{\circ} \mathrm{C}$ when compared to diesel $358^{\circ} \mathrm{C}$. The analysis of the combustion process for $\mathrm{E} 30$ emulsion fuel with variations in the air mass flow rate added showed the peak cylinder pressure at high loads was at $0.018 \mathrm{~kg} / \mathrm{s}$ at a pressure of 5.86 bar. Meanwhile, the optimum heat release rate at high loads was obtained at a variation of $0.013 \mathrm{~kg} / \mathrm{s}$. As a conclusion, adding air mass flow rate to the E30 emulsion fuel has the ability to improve performance and reduce engine emissions.

Keywords: Diesel engine; Mass flow rate; Emulsion; BMEP

\begin{abstract}
Abstrak
Penelitian ini bertujuan untuk menguji penambahan laju aliran massa udara ke dalam ruang bakar menggunakan bahan bakar emulsi E30 (70\% air $+30 \%$ dex $+2 \%$ surfaktan tween $80+$ span 80$)$ pada mesin diesel stasioner Diamond DI 800 pada 1500 rpm. Performa mesin dievaluasi menggunakan alat combustion analyzer dan emisi diukur dengan engine gas analyzer. Hasil penelitian menunjukkan penambahan laju aliran massa udara mempengaruhi kinerja mesin dan emisi. Daya keluaran diamati mengalami penurunan sebesar 0,016\%, sementara SFC dan efisiensi termal masing-masing meningkat sebesar 2,077\% dan 33,053\% dibandingkan dengan bahan bakar diesel. Selain itu, BMEP dan suhu gas buang juga menurun, penurunan paling optimal di BMEP ditemukan 0,02\% dan penurunan suhu gas buang paling optimum pada $285^{\circ} \mathrm{C}$ jika dibandingkan diesel $358{ }^{\circ} \mathrm{C}$. Analisis proses pembakaran untuk bahan bakar emulsi E30 dengan variasi laju aliran massa udara yang ditambahkan menunjukkan tekanan silinder puncak pada beban tinggi berada pada 0,018 kg/s pada tekanan 5,86 bar. Sementara itu, laju pelepasan panas optimal pada beban tinggi diperoleh pada variasi $0,013 \mathrm{~kg} / \mathrm{s}$. Sebagai kesimpulan, menambahkan laju aliran massa udara ke bahan bakar emulsi E30 memiliki kemampuan untuk meningkatkan kinerja dan mengurangi emisi mesin.
\end{abstract}

Kata-kata kunci: Mesin diesel; Laju aliran massa; Emulsi; BMEP 


\section{Introduction}

Fossil fuels affect climate change by contributing $76 \%$ to the total greenhouse gases with the largest contribution reported to be from transportation and industry emissions [1]. This has led to the development of fuel-based emissions control solutions without relying on hardware to control combustion and emissions processes [2]. This technology involves using alternative fuels by adding water to the combustion chamber and this method is considered effective to control emission in diesel engines. The water can be added using four methods such as water injection at the intake manifold, direct water injection with a separate nozzle, multilevel diesel-air-diesel injection, and the use of water-emulsified diesel [3]. Meanwhile, water emulsion is the water dissolved into the diesel fuel with the help of a binder in the form of a surfactant [4]. The instability of these two phases can be controlled using an emulsifier or emulgator [5].

There are, however, several problems attached to water emulsion fuels in diesel, for example, it creates a longer ignition delay due to a decrease in air temperature caused by water evaporation [4] [6] - [8]. The micro-explosion phenomenon also affects the length of ignition delay due to the requirement of a longer time in the combustion process of water emulsions fuel compared to diesel fuel [9]. According to Lin and Wang [10], also found the use of emulsion fuels with $10 \%$ and $20 \%$ water content to have increased the value of the equivalent ratio and this made the fuel mixture richer compared to the use of pure diesel. An average decrease in air-fuel ratio (AFR) and oxygen value were also recorded in the exhaust emissions on $20 \%$ emulsion fuel at 10-15 kgf.m (98-147Nm) engine load. This was associated with the increase in the consumption of water emulsion fuels compared to diesel fuel. According to Hountalas et al. [11], the presence of water in the combustion chamber filling led to the entrance of air composition into the fuel zone, thereby, reducing oxygen availability and, at the same time, leaving some amount of fuel in the chamber. This, therefore, led to the slight reduction of the AFR value with a corresponding small negative effect on the combustion rate caused by BSFC, and the energy was absorbed by water.
The use of water emulsion fuels in oil also increases CO and HC emission levels [6] - [8], [12]. According to Ithnin et al. [13], they were able to reduce the $\mathrm{NOx}$ value while the $\mathrm{CO}$ emission levels increased with the water content in the emulsion fuels. Researcher Subramanian [14], reported its ability to increase $\mathrm{HC}$ and $\mathrm{CO}$ emissions in the low and partial load conditions, According to Kumar et al. [15] found this to be due to the reduced combustion temperature and the length of the ignition delay. This was further supported by Fahd et al. [16] that combustion with emulsion fuels has a higher $\mathrm{CO}$ emission value compared to the use of diesel fuel only due to lower temperatures. This is also in accordance with the submission of [17] that CO oxidation process freezes at a temperature lower than 1400 $\mathrm{K}$. This is due to the presence of water which makes the flame temperature of the emulsion fuel to be lower than in diesel, especially in low load conditions, and this is usually insufficient to convert $\mathrm{CO}$ to $\mathrm{CO}_{2}$. Furthermore, another research conducted by Papagiannakis [18] showed an increase in the air mass flow rate to cause a reduction in $\mathrm{HC}$ emissions. Meanwhile, a decrease in the total relative air-fuel ratio leads to a slight increase in unburned HC emissions, because the amount of fuel coming from the combustion process is lower, due to a substantial increase in the process. According to Nguyen's study [19], varying the AFR added caused a slight decrease in $\mathrm{HC}$ and $\mathrm{CO}$ emissions compared to the use of diesel fuel due to the lower availability of unburnt gas fuel in the cylinder. It also agrees with the findings of Heywood's study [17], that a volumetric efficiency causes a rise in the combustion chamber's pressure and temperature.

Based on these descriptions, it is important to analyze the influence of air mass flow rate addition and determine its ability to reduce emissions values, shorten ignition delay, and increase performance in emulsion-fueled diesel engines. The results are expected to show the influence of the air mass flow rate added to the combustion chamber using an electric supercharger on the combustion process of a diesel engine using the duration of combustion, cylinder pressure, combustion chamber temperature, heat release rate, and the resulting emissions as the indicators. 


\section{Materials and Method}

\subsection{Emulsions fuel preparations}

The fuels used include diesel (E0) and emulsion (E30) with their respective properties described in Table 1. The mixture was Emulsion (E30) Water $70 \%+$ Dex 30\%) + 2\% Surfactant Tween 80 and Span 80 , surfactant $2 \%$ out of $100 \%$ total.

A stirring was employed using an agitator mixer for 30 minutes and this involved the gradual addition of the surfactant to the emulsion mixture in the beaker glass with a magnetic stirrer applied to stir at a constant speed of $2000 \mathrm{rpm}$ [20]. The emulsion manufacturing process is presented in Table 2 and the product was stabilized using a sonicator for 60 minutes at $>20 \mathrm{kHz}$ frequency.

\subsection{Engine setup and procedures}

The study was conducted on a one-cylinder Diamon DI 800 diesel engine using diesel fuel (E0) and E30 emulsions and its specifications are presented in Table 3. The air mass flow rate used was varied between $0.013 \mathrm{~kg} . \mathrm{s}-1$ and $0.028 \mathrm{~kg} . \mathrm{s}-1$ with an interval of 0.005 . Moreover, the diesel engine with the emulsion fuel was operated at a constant speed of $1500 \mathrm{rpm}$ and connected to an electric generator with a 4000 watt and tested using the parameters listed in Table 4 . The air compressor or electric supercharger which was used to press the additional air into the engine combustion chamber was also applied to vary the air mass flow rate. Furthermore, the cylinder pressure and heat release rate (HRR) data were obtained using a Combustion Analyzer with Hardware Vibrasindo TMR-Card Board \& TMRCrank Angle-CPU specifications. Entry Level Cards, pressure transducers, and SYSMONSoft v2.0.3 software were also used to acquire, process, and analyze data while computers with licenses were used for data processing. $\mathrm{CO}$ and $\mathrm{HC}$ emissions were tested using a Gas Analyzer with 8980TC Stargas while PM was measured with Smoke Type 495/02OTC. The schematic diagram of the testing process is presented in Figure 1.

Table 1. Properties of emulsion fuel [6]-[8]

\begin{tabular}{lrr}
\hline \multicolumn{1}{c}{ Fuel properties } & Diesel $100 \%(\mathrm{E} 0)$ & Emulsion $30 \%(\mathrm{E} 30)$ \\
\hline Density at $40^{\circ} \mathrm{C}\left(\mathrm{kg} \cdot \mathrm{m}^{-3}\right)$ & 840 & 853.3 \\
Calorie value $\left(\mathrm{kj} \cdot \mathrm{kg}^{-1}\right)$ & 46189.19 & 31119.3 \\
Viscosity at $40^{\circ} \mathrm{C}\left(\mathrm{mm}^{2} . \mathrm{s}^{-1}\right)$ & 3.9 & 4.46 \\
Flash Point $\left({ }^{\circ} \mathrm{C}\right)$ & 55 & 80 \\
\hline
\end{tabular}

Table 2. Emulsion process

\begin{tabular}{cccc}
\hline Emulsion process & $\begin{array}{c}\text { Mixing process } \\
\text { (minute) }\end{array}$ & $\begin{array}{c}\text { Stabilizer process } \\
\text { (minute) }\end{array}$ & $\begin{array}{c}\text { Stability process } \\
\text { (day) }\end{array}$ \\
\hline $\begin{array}{l}\text { Diesel (Dex) 70\% + Water (Aqua des) 30\% } \\
+ \text { Surfactant 2\% (Span 80 \& Tween 80) }\end{array}$ & 30 & 60 & 6 \\
\hline
\end{tabular}

Table 3. Specifications of diesel-emulsion engine

\begin{tabular}{ll}
\hline Parameters & Specifications \\
\hline Brand & Diesel Diamond \\
Type & DI 800 \\
Model & One-Cylinder, Four-Stroke \\
Bore $x$ Stroke & $82 \mathrm{~mm} \times 78 \mathrm{~mm}$ \\
Displacement & $411 \mathrm{cc}$ \\
Max. Power & $5.9 \mathrm{HP}(4.4 \mathrm{KW}) / 2000 \mathrm{rpm}$ \\
Continuous Power & $4.8 \mathrm{HP}(3.6 \mathrm{KW}) / 1500 \mathrm{rpm}$ \\
Compression Ratio & $18: 1$ \\
Cooling System & Hopper \\
Lube Capacity & $1.8 \mathrm{~L}$ \\
Injection Timing & $13{ }^{\circ} \mathrm{BTDC}$ \\
\hline
\end{tabular}

Table 4. Parameters tested on diesel engines with emulsion fuel

\begin{tabular}{cccc}
\hline Rotation $(\mathrm{rpm})$ & Load (Watt) & Mass Flow Rate $\left(\mathrm{kg} \cdot \mathrm{s}^{-1}\right)$ & Fuel \\
\hline 1500 & 4000 & Standard Diesel & Diesel 100\% (E0) \\
1500 & 4000 & $0.013-0.028$ intervals 0.005 & Emulsion $30 \%$ (E30) \\
\hline
\end{tabular}




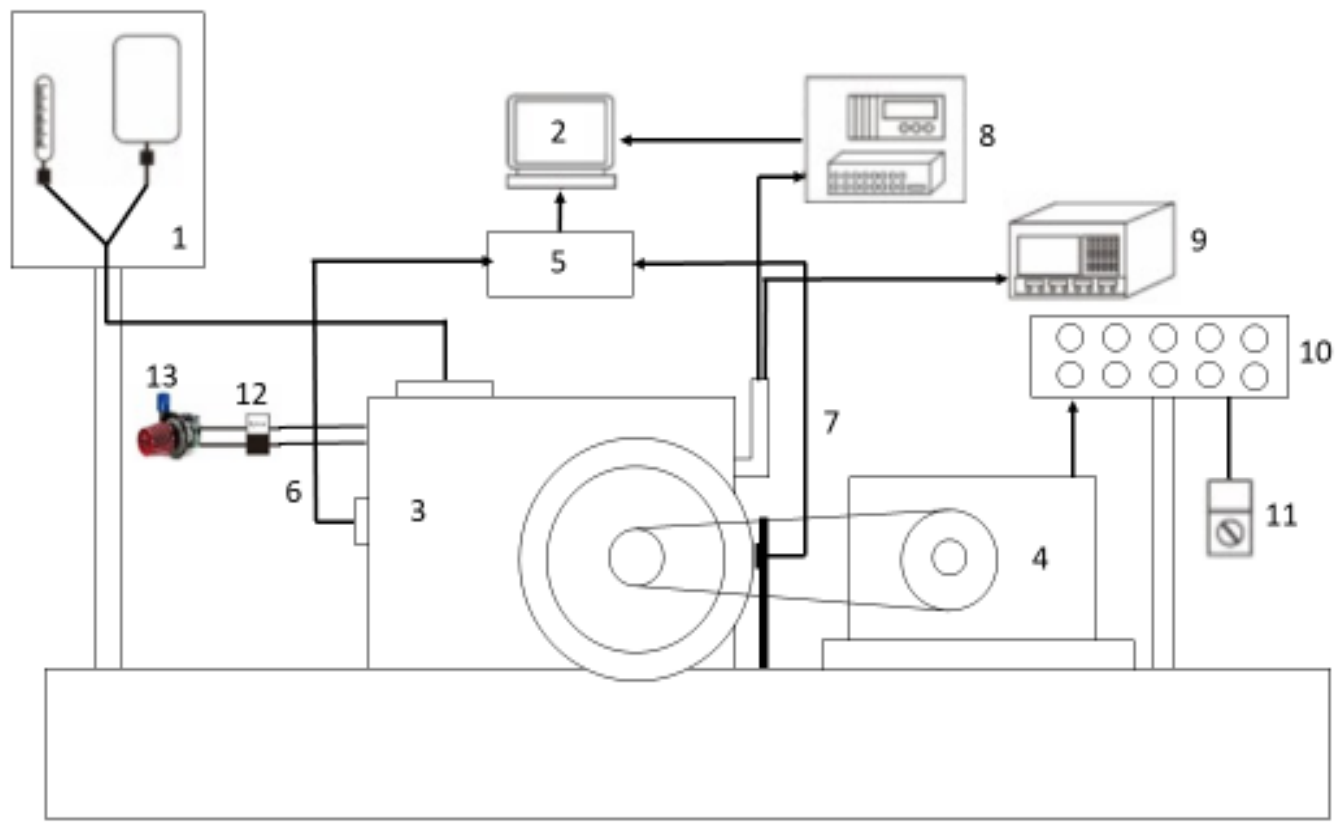

Figure 1. The experimental scheme: (1) fuel tank; (2) data acquisition system; (3) diesel engine; (4) generator DC; (5) combustion analyzer; (6) pressure sensor; (7) crank angle sensor; (8) thermocouple; (9) emission analyzer; (10) load; (11) multimeter; (12) manometer; and (13) electric supercharger.

\section{Resuts and Discussion}

This discussion covers the effect of air mass flow rate on diesel engines with E30 emulsion fuels under high loads using three variables including engine performance with power, SFC, BMEP, thermal efficiency, and exhaust temperature as indicators, combustion process with cylinder pressure, HRR, ignition delay, and combustion duration as indicators, and exhaust emissions with $\mathrm{HC}, \mathrm{CO}$, and $\mathrm{PM}$ as indicators.

\subsection{Effect of air mass flow rate and emulsion fuel on engine performance}

3.1.1. The engine power, SFC, and thermal efficiency

Figure 2 shows the load increased by $0.097 \%$ due to the addition of air mass flow rate at 0.018 $\mathrm{kg} / \mathrm{s}$ and decreased by $0.203 \%$ and $0.744 \%$ at 0.023 $\mathrm{kg} / \mathrm{s}$ and $0.028 \mathrm{~kg} / \mathrm{s}$, respectively. In comparison with diesel fuel without variation, the E30 emulsion decreased with the lowest value recorded to be $0.016 \%$ at $0.018 \mathrm{~kg} / \mathrm{s}$. Moreover, the reduction found with variations $0.018 \mathrm{~kg} / \mathrm{s}$ and $0.023 \mathrm{~kg} / \mathrm{s}$ were $0.316 \%$ and $0.858 \%$ respectively while the optimum results was recorded at 0.018 $\mathrm{kg} / \mathrm{s}$ with a power reduction value of $0.016 \%$. At high loads, the amount of fuel injected into the combustion chamber increased to keep the engine speed constant. This, therefore, shows the energy needed for the engine power increased according to the load provided.

Figure 2 also shows the addition of the air mass flow rate to the emulsion produced the most optimum decrease of $13.68 \%$ in SFC at $0.023 \mathrm{~kg} / \mathrm{s}$ while the value increased at $0.028 \mathrm{~kg} / \mathrm{s}$. In comparison with diesel fuel, E30 emulsion fuel experienced the highest increase at $0.013 \mathrm{~kg} / \mathrm{s}$ by $15.476 \%$ while the lowest was at $0.023 \mathrm{~kg} / \mathrm{s}$ by $2,077 \%$. This means diesel was more wasteful considering the fact that it has a higher heating value compared to the emulsion fuel. This was confirmed by Fahd et al. [16] that the SFC for emulsion fuels is higher than diesel fuel due to its low heating value which increases fuel consumption to obtain the same power. Moreover, the SFC equation shows the SFC power is only influenced by the magnitude of changes in engine power $(\mathrm{Ne})$ and the mass of diesel fuel. Engine power increases with electricity loads and this, therefore, reduces diesel fuel consumption time. However, the optimal condition of the air mass flow rate was observed at $0.023 \mathrm{~kg} / \mathrm{s}$ where the time and power produced the lowest SFC value. The AFR always changes based on the load provided while testing a constant rotation machine but not every of its value has the ability to produce optimal combustion. At low loads, a poorer AFR mixture is formed and this means 
more fuel mixture is required to produce an effective power of $1 \mathrm{KW}$ for 1 hour. At high loads, it tends towards a richer mixture but not all are capable of producing an effective power of $1 \mathrm{KW}$. The graph of E30 emulsion thermal efficiency towards the air mass flow rate is also presented in Figure 2 and it shows the thermal efficiency tends to be increasing with the mass flow rate. This is evident in the increment of $21,246 \%$ found at 0.013 $\mathrm{kg} / \mathrm{s}$ and the highest value of $33,053 \%$ at $0.028 \mathrm{~kg} / \mathrm{s}$ recorded due to the need for more fuel consumption to produce $1 \mathrm{~kW}$ of power which further leads to an increase in thermal efficiency.

The air mass flow rate added in the E30 emulsion fuel increased in each variation and this also caused an increment in the thermal efficiency from $0.013 \mathrm{~kg} / \mathrm{s}$ to $0.018 \mathrm{~kg} / \mathrm{s}$ by $6.624 \%$ as well as the highest value of $14.992 \%$ recorded at 0.028 $\mathrm{kg} / \mathrm{s}$. The increase was also associated with the low heating value (LHV) of the E30 emulsion as well as an increment in air mass flow rate which makes the fuel mass flow rate increase while having a lower LHV than diesel. Meanwhile, when the SFC is reaching a minimum value, the thermal efficiency tends to reach a maximum value. Therefore, the thermal efficiency produced by E30 emulsion fuels with lower heating values is greater than diesel fuel at the same power.

\subsubsection{BMEP, exhaust temperature}

The BMEP graph presented in Figure 3 shows the E30 emulsion fuels without any variation in

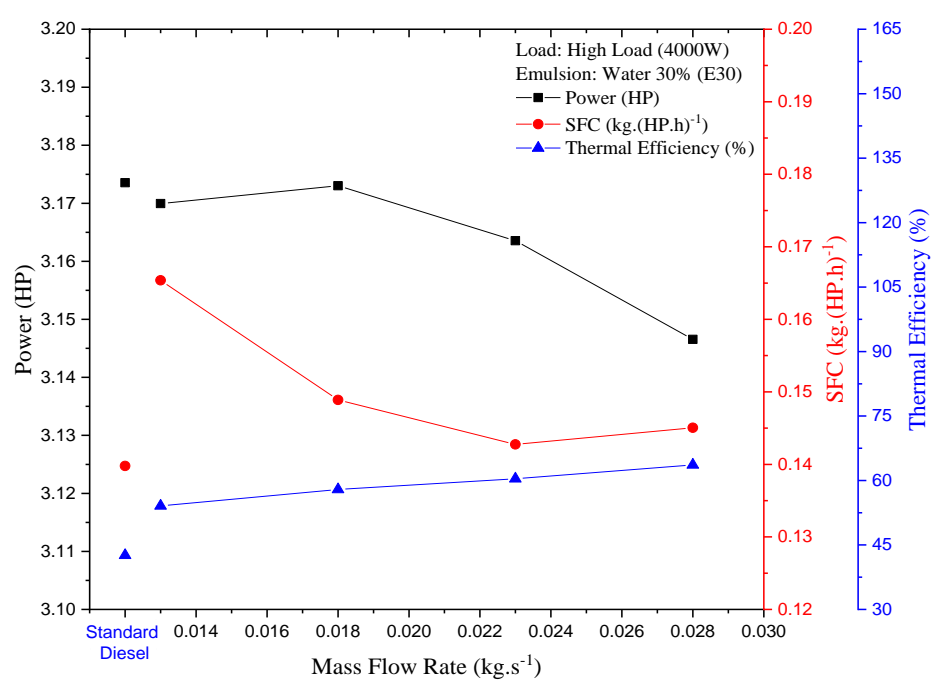

Figure 2. Effect of the air mass flow rate on engine power, SFC, and thermal efficiency

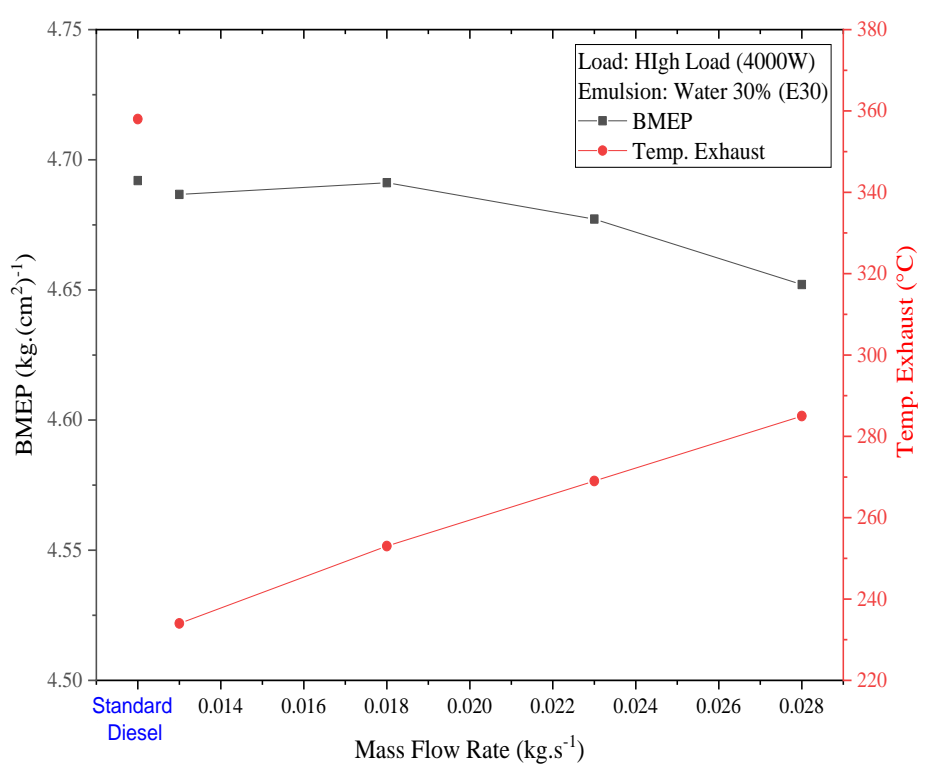

Figure 3. Effect of the air mass flow rate on BMEP and exhaust temperature 
the air mass flow rates decreased by $0.11 \%$ but at a variation of $0.018 \mathrm{~kg} / \mathrm{s}$ decreased by $0.02 \%$ and at $0.023 \%$ by $0.32 \%$ while the greatest, $0.86 \%$, was recorded at $0.028 \mathrm{~kg} / \mathrm{s}$. This means the optimum result was found at $0.018 \mathrm{~kg} / \mathrm{s}$. However, high loads have the ability to change AFR (air-fuel ratio) towards the fuel-rich mixture. More fuel burned in the combustion chamber leads to a greater generation of expansionary pressure and this further causes an increase in BMEP due to the increment in the load. An average effective pressure works along the piston stroke volume to produce power equal to the effective power and this usually occurs due to the combustion process in the chamber. Meanwhile, the amount of pressure varies along the piston stroke. According to Papagiannakis [18], setting air-fuel ratio using a supercharger and varying BMEP at 1.2, 2.4, 3.4, and 4.9 bar showed each $\mathrm{CO}$ gas emission decreased as the BMEP variation increased and this was associated to the lower availability of unburnt gas fuel inside the cylinder load due to an increase in the fuel combustion quality.

The effect of the E30 emulsion fuel on the exhaust temperature based on the air mass flow rate added is also presented Figure 3. The results showed an increase in exhaust temperature due to the addition of the air mass flow rate due to the increment in the amount of energy inputted into the combustion chamber to produce power. The E30 emulsion fuel without variation showed an increase in exhaust temperature reaching $234{ }^{\circ} \mathrm{C}$ but this is low compared to diesel which has the ability to reach $358^{\circ} \mathrm{C}$ at high loads. Moreover, the addition of air mass flow rate at $0.028 \mathrm{~kg} / \mathrm{s}$ reached $285^{\circ} \mathrm{C}$ and this was considered the optimal result because it below diesel by $25.61 \%$.

\subsection{Effect of air mass flow rate and emulsion fuel on the combustion process}

3.2.1. The cylinder pressure and HRR

Figure 4 shows the results for the cylinder pressure and Heat Release Rate of the crank angle function. At high loads, the cylinder chamber temperatures were high and this caused a reduction in the ignition delay and made the Start of Combustion (SOC) longer. The cylinder pressure in diesel fuel was 62 bar with a heat release rate of $17,006 \mathrm{~kJ} / \mathrm{m}^{3} / \mathrm{deg}$ while the value for the E30 emulsion fuel without variation decreased by $2.4 \%$ with a peak pressure of 58.006 bar and an average heat release rate at $30.03 \mathrm{~kJ} / \mathrm{m}^{3} / \mathrm{deg}$ which was $2.3 \%$ higher than the value for diesel. However, a peak cylinder pressure of 59.682 bar and an average value of heat release rate of 29.243 $\mathrm{kJ} / \mathrm{m}^{3} / \mathrm{deg}$ were recorded at a variation of 0.028 $\mathrm{kg} / \mathrm{s}$. This generally means using E30 emulsions made the emulsion pressure peak lower than the Top Dead Center (TDC) due to the low combustion chamber temperature thereby causing a long ignition delay. This is in line with the findings of Fadh study [16] that a pressure drop and a long ignition delay occur due to a low LHV value.

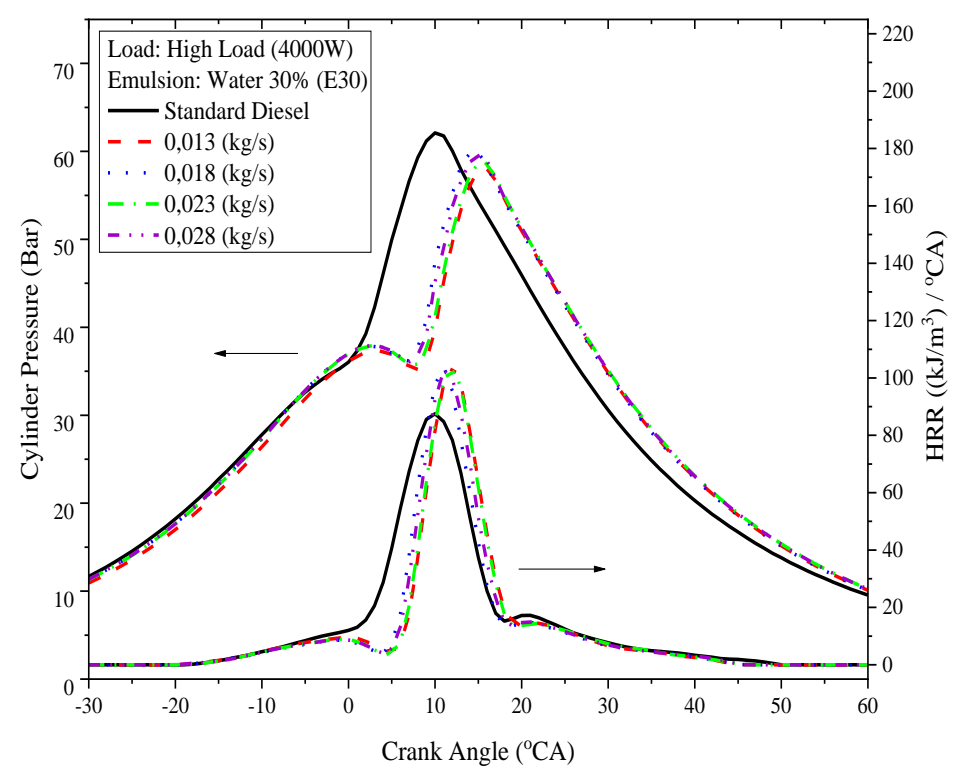

Figure 4. Effect of the air mass flow rate on HRR, and cylinder pressure 
Moreover, two peaks were observed in the E30 emulsion fuel due to the micro-explosion process which occurred shortly after the fuel was sprayed in the combustion chamber and atomized with air. The water content in the fuel caused the microexplosion intensity to be strong and also elongated the explosion duration. The process, therefore, encouraged better atomization and airfuel mixture to produce combustible fuel and high peak combustion pressures. A contrasting trend can also be found at the heat release rate during premix and diffusion combustion. It is important to note that the heat release rate is an engine performance in combustion which can be obtained and analyzed from direct pressure drop measured during the combustion process in the cylinder [21]-[23]. It is directly proportional to the inner energy and cylinder pressure - the combustion performance produced from the heat between air and fuel.

\subsubsection{Ignition delay and combustion duration}

The graph of ignition delay and combustion duration on a diesel engine using E3 emulsion fuel is shown in Figure 5. A grace period is observed in a diesel engine such that during the start of the injection, the pressure and temperature increase to a certain condition due to the pressing motion of the piston and this makes the air-fuel mixture experiences an initial fire point in the combustion chamber before it burns [21]. Therefore, an ignition delay is a parameter affecting the whole combustion process from the beginning to the end with further effects on the performance and emissions generated from the engine. It is calculated from the initial period of fuel injection (start of injection) up to the combustion stage (Start of combustion).

Meanwhile, the combustion duration is the time between the moment combustion starts (start of combustion) up to the period it ends (end of combustion) and is calculated from the burning curve of mass fraction and cumulative heat release rate. The initial combustion is determined by the minimum cumulative heat released while the maximum indicated the end. At a greater addition of mass flow rate to the E30 emulsion fuel, the combustion duration was observed to be shorter and increased with the load. This is associated with the rich mixture in $0.013 \mathrm{~kg} / \mathrm{s}$ which caused an increase in the combustion duration. However, an increase in the rate made the mixture to be thin and the combustion duration became shorter while the ignition delay became longer due to increased volumetric efficiency and cylinder pressure.

\subsection{Effect of the air mass flow rate and emulsion fuel on emission exhaust}

The graph of $\mathrm{CO}$ emissions from E30 emulsion fuels is shown in Figure 6 and the results showed the emissions are dangerous and formed from incomplete fuel combustion. For example, combustion without oxygen produces $\mathrm{CO}$ in the unburnt fuel released with the exhaust gases. Carbon monoxide also tends to arise at high

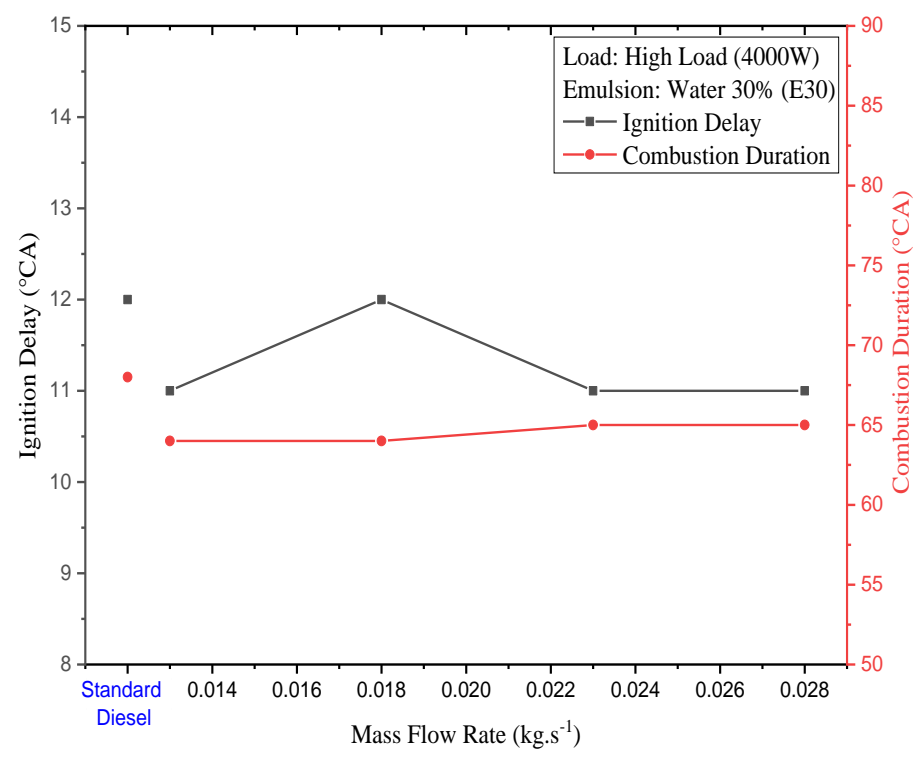

Figure 5. Effect of the air mass flow rate on ignition delay, and combustion duration 
combustion temperatures even in poor mixtures with enough oxygen due to the dissociation of the carbon dioxide to form carbon monoxide and oxygen. The results showed the $\mathrm{CO}$ emissions decreased as more air mass flow rate was added and this was observed with the $9.5 \%$ reduction with $0.018 \mathrm{~kg} / \mathrm{s}, 19.05 \%$ in $0.023 \mathrm{~kg} / \mathrm{s}$, and the most optimum of $45.3 \%$ recorded for $0.028 \mathrm{~kg} / \mathrm{s}$. Meanwhile, using E30 emulsion fuel without variation increased by $70.3 \%$ in comparison with diesel and this was associated with the lower exhaust temperature of the E30 emulsion which made the oxidation of $\mathrm{CO}$ and $\mathrm{O}_{2}$ to form $\mathrm{CO}_{2}$ impossible. This is in accordance with the findings of Ithnin study [13] that it is impossible for the $\mathrm{CO}_{2}$ oxidation process to occur at exhaust temperature below $140 \mathrm{~K}$ thereby causing a high level of $\mathrm{CO}$ emission.

The reduction in combustion chamber temperature is caused by the micro-explosion process which not only improves the process of mixing fuel with air but also decreases the temperature of the combustion flame as explained by Park [24] and Endah [25]. Therefore, the variations of $0.013 \mathrm{~kg}, 0.018 \mathrm{~kg} / \mathrm{s}, 0.023 \mathrm{~kg} / \mathrm{s}$, and $0.028 \mathrm{~kg} / \mathrm{s}$ caused an increase in volumetric efficiency thereby leading to an increment in the pressure and temperature. The temperature increase makes $\mathrm{CO}$ and $\mathrm{O}_{2}$ oxidation possible and this further reduces the $\mathrm{CO}$ emissions value. At high load, the highest value was recorded at 0.013 $\mathrm{kg} / \mathrm{s}$ while the lowest was at $0.028 \mathrm{~kg} / \mathrm{s}$. This is in line with the results of Papagiannakis study [18] that increasing the mass airflow rate reduces HC and $\mathrm{CO}$ emissions. Moreover, adding air mass flow rate has the ability to produce an ideal AFR value which further causes a reduction in the emissions even though it is still above the diesel value.

The effects of using diesel fuel and E30 emulsions on $\mathrm{HC}$ emissions are also presented in Figure 6 and the results showed the addition of air mass flow rate decreased the $\mathrm{HC}$ emission for both fuels. Hydrocarbons are emissions formed due to incomplete combustion, according to Subramanian investigation [14], water emulsion fuels in oil have the ability to increase $\mathrm{HC}$ and $\mathrm{CO}$ emissions in the low and partial loads conditions.

However, the results showed the highest value for E30 emulsion was recorded at a variation of $0.013 \mathrm{~kg} / \mathrm{s}$ with an increase of $45 \%$ while the lowest and closest to diesel was at $0.028 \mathrm{~kg} / \mathrm{s}$. This is in line with the findings of Papagiannakis study [18] that adding air mass flow rate has the ability to reduce $\mathrm{HC}$ and $\mathrm{CO}$ emissions. This is due to the increment in volumetric efficiency which causes an increase in the pressure and temperature to further reduce the $\mathrm{HC}$ emissions even though the value is more than what is recorded for diesel.

Another important result presented in Figure 6 is the graph on the effect of emulsions and diesel on smoke emissions due to the addition of the air mass flow rate. The first trend showed the use of E30 emulsion fuels has the ability to reduce smoke emissions as observed with the $77.4 \%$ reduction recorded without variation, $67.9 \%$ for $0.018 \mathrm{~kg} / \mathrm{s}$,

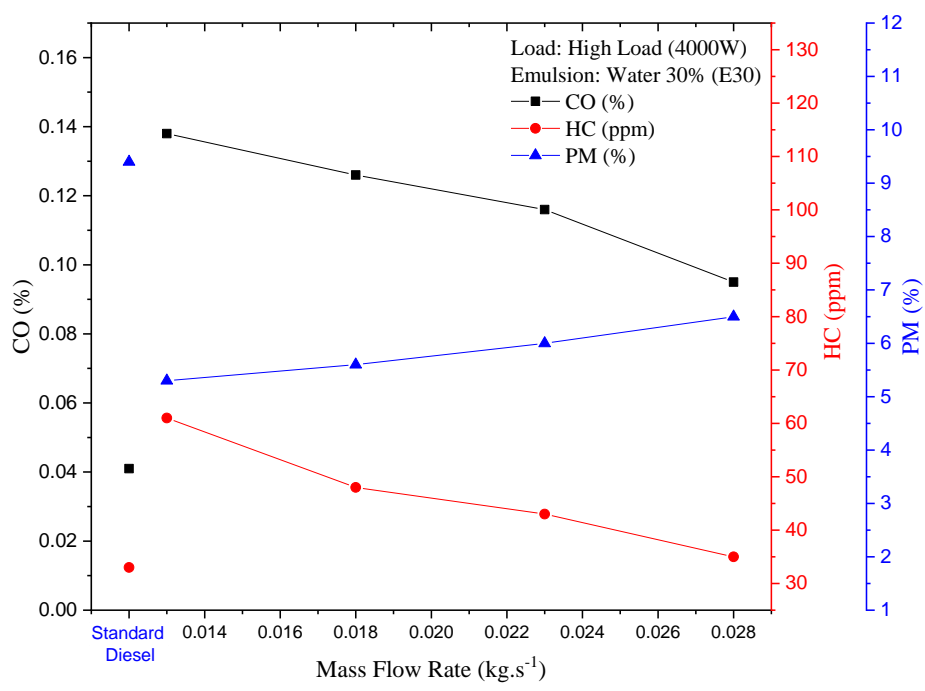

Figure 6. Effect of the air mass flow rate on $\mathrm{CO}, \mathrm{HC}$, and $\mathrm{PM}$ 
$56.7 \%$ for $0.023 \mathrm{~kg} / \mathrm{s}$, and the most optimum value of $44.6 \%$ for $0.028 \mathrm{~kg} / \mathrm{s}$. Moreover, the exhaust gas smoke reduced due to the increase in air mass flow rate as evident in $5.4 \%$ caused by $0.018 \mathrm{~kg} / \mathrm{s}$, $11.7 \%$ by $0.023 \mathrm{~kg} / \mathrm{s}$, and $18.5 \%$ by $0.028 \mathrm{~kg} / \mathrm{s}$. This was associated with the tendency of the combustion process to become more perfect with the increasing air mass flow rate.

\section{Conclusions}

This study examines the effect of micro emulsion method on combustion parameters. The results showed that diesel + water mixture was effective in combustion parameters. The use of E30 emulsion fuel in diesel engines with variations of air mass flow rate was found to have the optimal power value at $0.018 \mathrm{~kg} / \mathrm{s}, \mathrm{SFC}$ at 0.023 $\mathrm{kg} / \mathrm{s}$, and thermal efficiency at $0.028 \mathrm{~kg} / \mathrm{s}$ which increased by 33\% compared to diesel. The analysis of the combustion process showed the peak cylinder pressure at high loads was at $0.018 \mathrm{~kg} / \mathrm{s}$ with a 59.86 bar while the optimum heat release rate was at $0.013 \mathrm{~kg} / \mathrm{s}$. Moreover, the $\mathrm{HC}$ and CO emissions were found to be increasing with the air mass flow rate but decreased significantly at 0.028 $\mathrm{kg} / \mathrm{s}$ compared to diesel but PM emissions at high load were recorded to have reduced only by $30 \%$ compared to diesel. Therefore, the most optimum mass flow rate to be added for power, BMEP, ignition delay, combustion duration was 0.018 $\mathrm{kg} / \mathrm{s}$ while the optimum for emissions, thermal efficiency, and exhaust temperature was 0.028 $\mathrm{kg} / \mathrm{s}$ but $0.023 \mathrm{~kg} / \mathrm{s}$ for SFC.

\section{Acknowledgment}

The research was conducted at the Combustion and Energy Systems laboratory in the Department of Mechanical Engineering and Fundamental Laboratory of the Department of Chemistry, Institut Teknologi Sepuluh Nopember Surabaya (ITS), Indonesia.

\section{Author's Declaration \\ Authors' contributions and responsibilities \\ The authors made substantial contributions to the conception and design of the study. The authors took responsibility for data analysis, interpretation and discussion of results. The authors read and approved the final manuscript.}

\section{Funding}

No funding information available from the authors.

\section{Availability of data and materials}

All data are available from the authors.

\section{Competing interests}

The authors declare no competing interest.

\section{Additional information}

No additional information from the authors.

\section{References}

[1] R. K. Pachauri And L. Meyer, Climate Change 2014: Synthesis Report. Contribution Of Working Groups I, II And III To The Fifth Assessment Report Of The IPCC. 2015.

[2] M. Yahaya Khan, Z. A. Abdul Karim, F. Y. Hagos, A. R. A. Aziz, And I. M. Tan, “Current Trends In Water-In-Diesel Emulsion As A Fuel," Sci. World J., Vol. 2014, No. January, 2014, Doi: 10.1155/2014/527472.

[3] J. Sadhik Basha And R. B. Anand, "An Experimental Investigation In A Diesel Engine Using Carbon Nanotubes Blended Water-Diesel Emulsion Fuel," Proc. Inst. Mech. Eng. Part A J. Power Energy, Vol. 225, No. 3, Pp. 279-288, 2011, Doi: $10.1177 / 2041296710394247$.

[4] M. T. Ghannam And M. Y. E. Selim, "Stability Behavior Of Water-In-Diesel Fuel Emulsion," Pet. Sci. Technol., Vol. 27, No. 4, Pp. 396-411, 2009, Doi: 10.1080/10916460701783969.

[5] M. R. Noor El-Din, S. H. El-Hamouly, H. M. Mohamed, M. R. Mishrif, And A. M. Ragab, "Water-In-Diesel Fuel Nanoemulsions: Preparation, Stability And Physical Properties," Egypt. J. Pet., Vol. 22, No. 4, Pp. 517-530, 2013, Doi: 10.1016/J.Ejpe.2013.11.006.

[6] Rosid, B. Sudarmanta, L. Atmaja, I. S. Krisandika, And A. W. Arohman, "Effect Of 35\% Water In Diesel Emulsion Fuel And Afr Enriched Combustion On The Combustion And Emissions Characteristics," AIP Conf. Proc., Vol. 2187, No. December, 2019, Doi: 10.1063/1.5138301.

[7] B. Sudarmanta, Rosid, I. S. Krisandika, And A. W. Arohman, "The Effect Of Advancing Injection Timing On Combustion Characteristics Using Stationary Diesel Engine With 30\% Water In Diesel Emulsion 
Fuel," AIP Conf. Proc., Vol. 2187, No. December, 2019, Doi: 10.1063/1.5138298.

[8] A. W. Arohman, B. Sudarmanta, And Rosid, "Influence Of Water Diesel Emulsion On The Performance And Emission Diesel Engine Under Varying Engine Load," AIP Conf. Proc., Vol. 2187, No. December, 2019, Doi: $10.1063 / 1.5138267$

[9] H. Kim And S. W. Baek, "Combustion Of A Single Emulsion Fuel Droplet In A Rapid Compression Machine," Energy, Vol. 106, Pp. 422-430, 2016, Doi: 10.1016/J.Energy.2016.03.006.

[10] C. Y. Lin And K. H. Wang, “Diesel Engine Performance And Emission Characteristics Using Three-Phase Emulsions As Fuel," Fuel, Vol. 83, No. 4-5, Pp. 537-545, 2004, Doi: 10.1016/J.Fuel.2003.08.012.

[11] D. T. Hountalas, G. C. Mavropoulos, T. C. Zannis, And S. D. Mamalis, "Use Of Water Emulsion And Intake Water Injection As Nox Reduction Techniques For Heavy Duty Diesel Engines," SAE Tech. Pap., Vol. 2006, No. 724, 2006, Doi: 10.4271/2006-01-1414.

[12] I. S. Krisandika, B. Sudarmanta, And Rosid, “Effects Of Advancing Injection Timing On The Engine Performances And Emissions Of A Diesel Engine With 35\% Water In Diesel Emulsion Fuel," AIP Conf. Proc., Vol. 2187, No. December, 2019, Doi: 10.1063/1.5138261.

[13] A. M. Ithnin, M. A. Ahmad, M. A. A. Bakar, S. Rajoo, And W. J. Yahya, "Combustion Performance And Emission Analysis Of Diesel Engine Fuelled With Water-In-Diesel Emulsion Fuel Made From Low-Grade Diesel Fuel," Energy Convers. Manag., Vol. 90, Pp. 375-382, 2015, Doi: 10.1016/J.Enconman.2014.11.025.

[14] K. A. Subramanian, "A Comparison Of Water-Diesel Emulsion And Timed Injection Of Water Into The Intake Manifold Of A Diesel Engine For Simultaneous Control Of No And Smoke Emissions," Energy Convers. Manag., Vol. 52, No. 2, Pp. 849-857, 2011, Doi: 10.1016/J.Enconman.2010.08.010.

[15] D. Maji, P. Mondal, And B. Kumar Mandal, “Experimental Investigation On The Use Of Water Emulsified Diesel In A Single Cylinder
Compression Ignition Engine," IOP Conf. Ser. Mater. Sci. Eng., Vol. 377, No. 1, 2018, Doi: $10.1088 / 1757-899 x / 377 / 1 / 012123$.

[16] M. E. A. Fahd, Y. Wenming, P. S. Lee, S. K. Chou, And C. R. Yap, "Experimental Investigation Of The Performance And Emission Characteristics Of Direct Injection Diesel Engine By Water Emulsion Diesel Under Varying Engine Load Condition," Appl. Energy, Vol. 102, Pp. 1042-1049, 2013, Doi: 10.1016/J.Apenergy.2012.06.041.

[17] J. B. Heywood, Internal Combustion Engine Fundamentals. New York: Mcgraw Hill Book Company, 1988.

[18] R. G. Papagiannakis, C. D. Rakopoulos, D. T. Hountalas, And D. C. Rakopoulos, "Emission Characteristics Of High Speed, Dual Fuel, Compression Ignition Engine Operating In A Wide Range Of Natural Gas/Diesel Fuel Proportions," Fuel, Vol. 89, No. 7, Pp. 13971406, 2010, Doi: 10.1016/J.Fuel.2009.11.001.

[19] Q. Nguyen And Y. Wu, "Experimental Investigations Of Using Water-Gasoline Emulsions As A Nox Treatment And Its Effects On Performance And Emissions Of Lean-Burn Spark-Ignition Engine," Int. Conf. Power Eng., Vol. 09, 2009.

[20] G. Chen And D. Tao, "An Experimental Study Of Stability Of Oil-Water Emulsion," Fuel Process. Technol., Vol. 86, No. 5, Pp. 499-508, 2005, Doi: 10.1016/J.Fuproc.2004.03.010.

[21] F. J. Zeleznik, B. J. McBride, Modeling the Internal Combustion Engine. Ohio: NASA, 1985.

[22] R. Rosid, "Analisa Proses Pembakaran Pada Motor Bensin 113.5 cc Dengan Simulasi Ansys," J. Teknol., Vol. 8, No. 2, P. 89, 2016, Doi: 10.24853/Jurtek.8.2.89-93.

[23] Rosid, "Analisis Proses Pembakaran Sistem Injection Pada Sepeda Motor Dengan Menggunakan Bahan Bakar Premium Dan Pertamax," J. Teknol., Vol. 7, No. 2, Pp. 86-92, 2015.

[24] J. W. Park, K. Y. Huh, And J. H. Lee, "Reduction Of NOx, Smoke and Brake Specific Fuel Consumption With Optimal 
Injection Timing And Emulsion Ratio Of Water-Emulsified Diesel," Proc. Inst. Mech. Eng. Part D J. Automob. Eng., Vol. 215, No. 1, Pp. 83-93, 2001, Doi: 10.1243/0954407011525476.
[25] P. Endah, R. Rosid, And S. Faizal, "Comparison Thermal Efficiency And Fuel Consumption Of Electric Supercharger Variations For Otto Engine," J. Appl. Sci. Adv. Technol., Vol. 1, No. 2, Pp. 63-68. 